\title{
CrimRxiv
}

\section{Narrative Analysis in Criminology}

Sveinung Sandberg

Published on: Jan 29, 2022

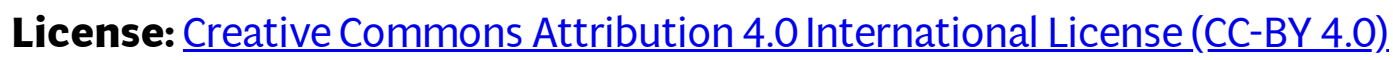


